Jpn. J. Limnol., 48, S107 S117. 1987.

\title{
Characteristics of Autochthonous Deposition and Resuspension of Sediments in the Takahamairi Bay of Lake Kasumigaura
}

\author{
Takehiko Fukushima, Morihiro AizAKI, and Kohji MuraOKA
}

\begin{abstract}
Deposition rates were measured by means of sediment traps at five stations in hypertrophic Takahamairi Bay of Lake Kasumigaura for the selected periods of 1981-1986. Separation of deposited fluxes into autochthonous and sediment resuspension components was attempted on the basis of chlorophyll a concentration for the tracer. Even at the central station of the bay, the average daily flux of autochthonous matter was $4 \mathrm{~g} \cdot \mathrm{m}^{-2} \cdot \mathrm{d}^{-1}$ compared with $46 \mathrm{~g} \cdot \mathrm{m}^{-2} \cdot \mathrm{d}^{-1}$ of resuspension. There was a time lag of one or two months between the peak of primary production and that of autochthonous deposited flux, which resulted in a surprising increase in chlorophyll $a$ concentration of lake water in mid-summer. Calculated autochthonous deposited rates of carbon, nitrogen, and phosphorus in backwater regions and near the inflow river mouth were much higher than those at offshore due to the contamination of allochthonous matter. In regard to the resuspension rates, a logarithmic decrease against water depth and significant correlations with some meteorological conditions were observed. The sum of autochthonous and allochthonous deposited fluxes exceeded the accumulation rates in sediments estimated both by the mass balance method and the sediment dating method by a factor of 8-17 for nitrogen and 2-10 for phosphorus, both of which were much larger than the ratios observed in other lakes. The shallowness of this lake greatly influenced these ratios because of the large resuspension rate followed by rapid decomposition in lake water and high activity of benthos.
\end{abstract}

Key words : autochthonous deposition, resuspension, sediment trap, nutrient cycle.

\section{Introduction}

Deposition of particulate matter is one of the fundamental processes governing lake nutrient cycles (Lastein, 1976; Bloesch et al., 1977). Although the theoretical aspects of sinking mechanisms of particles are complex and poorly understood, data on bulk particle flux provide insight into the lake ecosystem. Some aspects of the deposition process were studied with sediment traps in the Takahamairi Bay of Lake Kasumigaura. Our aims here are: (1) to separate the deposited flux into autochthonous and sediment resuspension components, (2) to explain the factors influencing autochthonous deposition and resuspension fluxes, (3) to compare the autochthonous deposited rates with primary production rates and the net sedimentation rates estimated both by the mass balance method and by the sediment dating method.

\section{Study sites and methods}

Lake Kasumigaura (surface area $171 \mathrm{~km}^{2}$; maximum depth $7.3 \mathrm{~m}$; mean depth $4.0 \mathrm{~m}$ ) is a shallow hypertophic lake composed of three basins (Fig. 1). The

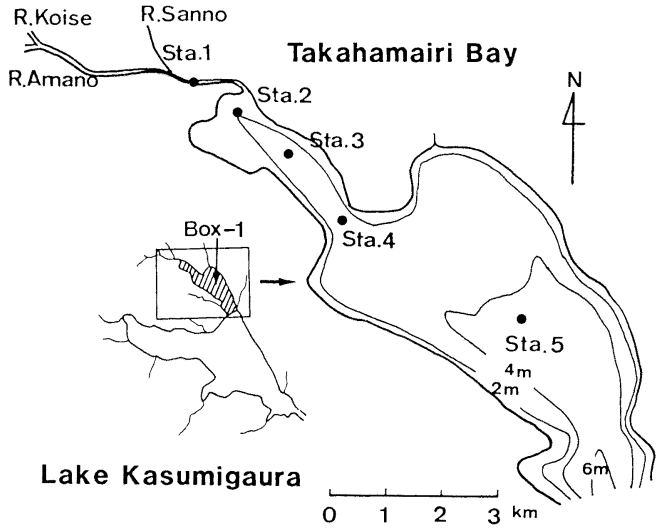

Fig. 1. Sampling stations in the Takahamairi Bay of Lake Kasumigaura.

Takahamairi Bay (surface area $23 \mathrm{~km}^{2}$; mean depth $3.2 \mathrm{~m}$ ) is one of the basins known to be highly eutrophicated. There is one main river named the 
River Koise at the north - west end (inflow about $3 \mathrm{~m}^{3} \cdot \mathrm{s}^{-1}$. Before the river mouth, River Sanno and River Amano joint River Koise).

At one station in the backwater region of River Koise (Sta. 1) and four stations in the lake (Sta. $2,3,4,5)$, deposition rates were measured for the three periods of July 1981 -October 1982, August 1983-October 1983, and April 1985-May 1986. Two parallel cylindrical traps $(25 \mathrm{~cm}$ high, $5.3 \mathrm{~cm}$ dia.) in a frame (Fukushima et al., 1984) were exposed with a simple mooring system using an anchor and subsurface buoys. The traps were set $0.5-1 \mathrm{~m}$ off the bottom. Traps were exchanged at intervals of 1 7 day from July to August and biweekly from September to June, the supernant water drained, and two samples of deposited matter (DM) were combined into one mixed sample for analysis.

For several selected periods, we checked (1) trapping efficiencies with various sediment traps of different size and shape, (2) the effect of exposure intervals on mineralization in traps, (3) the vertical difference in fluxes and compositions of deposited matter. As to (1), the cylindrical type was recommended as in the previous works (Gardner, 1980; Bloesch and Burns, 1980), and the differences of trap size $(0.5,1.5,2.0$ times as large as standard type) had a negligible effect on trapping efficiency (Fukushima et al., 1984). As to (2), the time intervals used in this study were thought to be appropriate to neglect the mineralization in the traps (Fukushima et al., 1984). The last problem (3) will be discussed in the following section.

Dry weight (DW) at $80^{\circ} \mathrm{C}$ and chlorophyll $a$ (Chla) were analyzed on a Whatman $\mathrm{GF} / \mathrm{C}$ glass - fiber filter. The concentration of Chla was determined by the UNESCO method (UNESCO, 1966). After the residual of the sample was freeze-dried, particulate organic carbon (POC) and nitrogen (PON) were measured with a CHN analyzer (Yanagimito MF3). Digested by potassium peroxodisulfate, the particulate phosphorus (PP) was determined with an auto-analyzer (Technicon Type-2). Concentrations of some metals such as $\mathrm{Ti}, \mathrm{Al}$ and $\mathrm{Fe}$ in selected DM were measured by the Takamatsu method (1978) using X-ray fluorescence spectromety (ORTEC TEFA MODEL-6111).

In addition to the sediment trap program, we obtained water sampls at all five stations. The suspended solids (SS), Chla, POC, PON, and PP were also measured by nearly the same method as DM. After being filtrated by nuclepore filter and digested by hydrofluoric acid and nitric acid, concentration of some metals in seston were determined by inductivity coupled plasma emission spectrometry (Jarrell-Ash Atomcomp Model-975, Okamoto and Fuwa, 1984). Sediment cores were collected over 20 times at each station, and the samples of $5 \mathrm{~mm}$ on the surface were analyzed by the same method as DM.

\section{Results and discussion}

\section{3-1. Separation of deposited matter}

Evaluating the settling process of the particulate matter in view of the nutrient cycles in lakes, it would be necessary to separate DM by origins and to count each component quantitatively. In a shallow lake of soft water, DM collected in sediment traps is mainly composed of autochthonous (bio-seston and detritus), allochthonous matter, and resuspended sediments. Two methods have been proposed for the separation of DM. The first is to collect one component during the period when other components would not be expected (Watanabe and Hayashi, 1971; Fuhs 1973). The second is to use the tracer's concentration which should be considerably different from the components. Organic matter (Gasith, 1975; Fallon and Brock, 1980), benthic animal(Lastein, 1976), and $\mathrm{Ti}$ (Matsunaga, 1982; Fukushima et al., 1988) have been examined for the tracer. Since the first method involves the difficulty in determing whether there is a calm period or not, we chose the second one.

Applying the second method, several prerequisites are thought to be necessary (Fukushima et al., 1988). The most important and most carefully examined problem is that one tracer could separate DM into only two components. Annual amounts of deposition observed from July 1981-June 1982 were $27.8 \times 10^{4}, 4.0 \times 10^{4}$, and $1.4 \times 10^{4} \mathrm{~g} \cdot \mathrm{m}^{-2} \cdot \mathrm{yr}^{-1}$ at Sta. 1 , 3 and 5 , respectively. Against these values, the sediment accumulation rate in the central basin was estimated to average $600-800 \mathrm{~g} \cdot \mathrm{m}^{-2} \cdot \mathrm{yr}^{-1}$ by several methods (Otsubo et al., 1984). Since the primary production rate was $615-751 \mathrm{gC} \cdot \mathrm{m}^{-2} \cdot \mathrm{yr}^{-1}$ for 1982-1983 in the Takahamairi Bay (Takamura et al., 1984), the autochthonous deposited flux would be on the order of $100 \mathrm{~g} \cdot \mathrm{m}^{-2} \cdot \mathrm{yr}^{-1}$, taking into account the POC content of autochthonous matter, respiration, and mineralization in the settling process. These figures indicate that the resuspension rate is much larger than the allochthonous and autochthonous deposited rate. By considering that 
the composition of allochthonous matter is similar to those of resuspended matter as described later, we could separate DM into resupeneded sediments and autochthonous matter.

From the mass balances of DM and tracer's substance, the ratio of autochthonous matter to total DM $(r)$ is given by

$$
\mathrm{r}=\left(\mathrm{C}_{\mathrm{d}}-\mathrm{C}_{\mathrm{s}}\right) /\left(\mathrm{C}_{\mathrm{a}}-\mathrm{C}_{\mathrm{s}}\right)
$$

in which $C_{d}, C_{a}, C_{s}$ are the tracer's concentration of DM, autochthonous matter, and resuspended sediments.

To calculate the value of $\mathrm{r}$ by this equation, (1) the value of $C_{s}$, (2) the value of $C_{a}$, (3) the substance for the tracer should be determined. As to (1), the tracer's concentration in the surface sediments of $5 \mathrm{~mm}$ was taken for the value of $\mathrm{C}_{\mathrm{s}}$. This depth nearly equals the depth to which it would be resuspended in stormy conditions (Fukushima et al., 1984). Table 1 shows the averages and standard deviations of POC, PON, PP, Chla, and Ti concentrations in the surface sediments at five stations.

With regard to (2) above, the concentration in seston has been employed for $C_{a}$ (Gasith, 1975). In the Takahamairi Bay, however, it frequently happens that the concentration in seston varies to a great extent (Sta. 3, POC (\%) $=27.8 \pm 11.9(\mathrm{n}=$ 51)). This fact implies that the seston in lake water contains the resuspended sediments and/or allochthonous matter. Figure 2 (1) and (2) show the relationship between $\mathrm{Ti}$ and $\mathrm{POC}$ concentrations in seston, and the relationship between $\mathrm{Ti}$ and Chla concentrations in seston, respectively. Including the value of sediments, linear relationships with negative slopes are found. Similar tendencies with respect to

Table 1. POC, PON, PP, Chla, and Ti concentration in the surface sediments $(0-5 \mathrm{~mm})$.

\begin{tabular}{|c|c|c|c|c|c|}
\hline & Sta. 1 & Sta. 2 & Sta. 3 & Sta.4 & Sta. 5 \\
\hline POC (\%) & $3.16^{1)} \pm 1.62^{23}(18)^{3)}$ & $4.97 \pm 0.45(23)$ & $5.26 \pm 0.85(23)$ & $5.85 \pm 0.84(23)$ & $6.45 \pm 0.70(24)$ \\
\hline PON (\%) & $0.27 \pm 0.18(18)$ & $0.47 \pm 0.15(23)$ & $0.65 \pm 0.13(23)$ & $0.70 \pm 0.15(23)$ & $0.73 \pm 0.19(24)$ \\
\hline PP (\%) & $0.15 \pm 0.07(17)$ & $0.23 \pm 0.01(24)$ & $0.25 \pm 0.02(24)$ & $0.23 \pm 0.01(24)$ & $0.17 \pm 0.03(24)$ \\
\hline Chla $\left(10^{-6} \mathrm{~g} \cdot \mathrm{g}^{-1}\right)$ & $92 \pm 55$ (17) & $97 \quad \pm 35$ & $147 \pm 58$ & $165 \pm 32$ & $184 \pm 68$ \\
\hline $\mathrm{Ti}(\%)$ & 0.470 & 0.492 & 0.510 & 0.463 & $0.370 \pm 0.016(8)$ \\
\hline
\end{tabular}

1) average, 2) standard deviation, 3) number of samplings

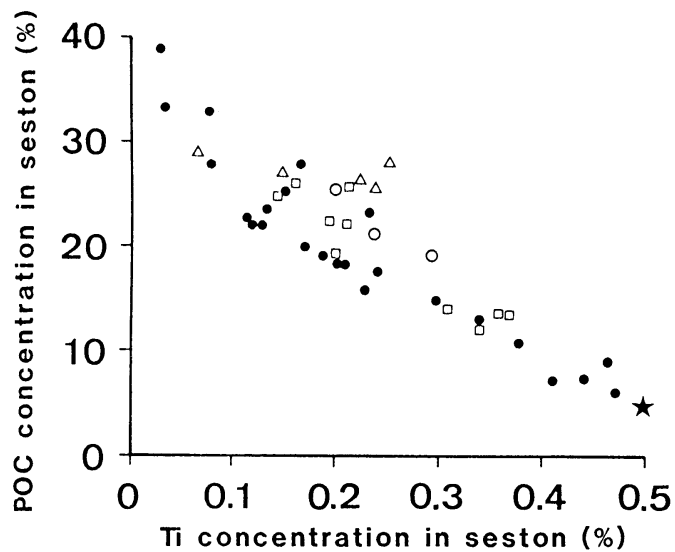

Fig. 2. (1) Relationship between $\mathrm{Ti}$ and $\mathrm{POC}$ concentrations in seston at Sta.3. $\bigcirc$ :July 1981-October 1981, $\square$ :November 1981-May 1982, $\triangle$ : June 1982-September 1982, and August 1983-October 1983, : August 1984May $1985, \star$ :sediments.

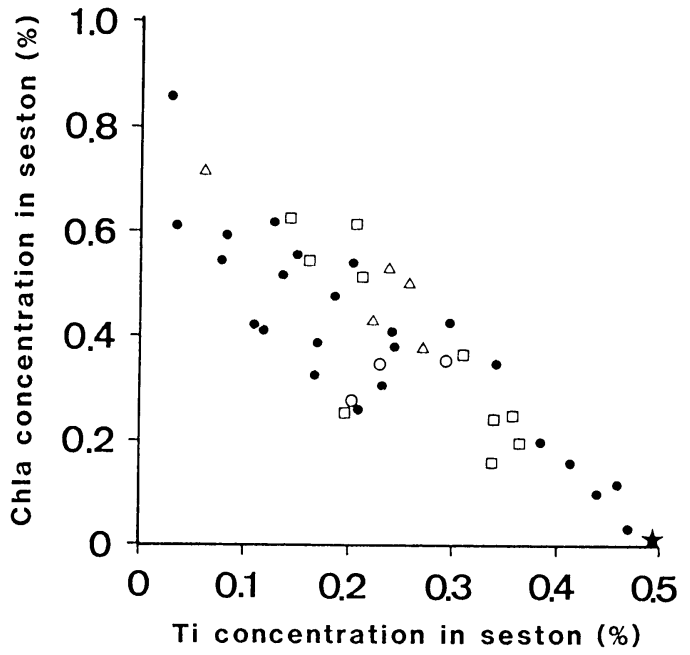

Fig. 2. (2) Relationship between $\mathrm{Ti}$ and Chlorophyll $a$ concentrations in seston at Sta.3. Symbols are explained in Fig. 2, (1). 
PON and PP existed in place of POC or Chla. Because of the much smaller $\mathrm{Ti}$ concentration in phytoplankton than seston $\left(0-137 \mu \mathrm{g} \cdot \mathrm{g}^{-1}\right.$, (Matsunaga, 1982)), the $\mathrm{Ti}$ concentration in seston would represent the rate of resuspended or allochthonous matter.

Since the amount of seston in lake water is several times as high as that in river water except during the direct runoff period, it is presumed that resuspended matter occupies a larger portion of seston than allochthonous matter (Fukushima et al., 1987). The intercept of the regression line at $\mathrm{Ti}=$ $0 \%$, consequently, gave the value of autochthonous matter composition. The POC, PON, PP, and Chla concentrations obtained in this way are summarized in T1-T4 (four different periods) of Table 2. There were some differences in these concentrations due to the different sampling periods. Stational variations were smaller than these differences. The compositions of Aoko (mainly blue-green algae collected in Lake Kasumigaura (Takamura et al., 1981)) and oceanic phytoplankton (Richards et al., 1965) are also shown in Table 2 and agree closely with the above-mentioned values.

As to (3) mentioned above, Table 3 shows the POC, PON, PP, Chla, and particulate titanium $(\mathrm{P}-\mathrm{Ti})$ concentrations in lake and river water. The concentrations in lake water are higher than those in river water except for $\mathrm{P}-\mathrm{Ti}$, but more than ten times the differences are found particularly in Chla. By using Chla for the tracer, it would be implied that the probability of the risk to mistake allochthonous deposited matter for autochthonous deposited matter is minimized. An excellent agreement between the value of $r$ with the aid of $\mathrm{Ti}$ and that with the aid of Chla may further reveal the appropriateness of the selection of Chla (Fukushima et al., 1984).

Applying the above method, the deposited rate of autochthonous matter $\mathrm{Q}^{\text {ss }}{ }_{\text {auto }}$ is given by

$$
\mathrm{Q}^{\text {ss }}{ }_{\text {auto }}=\mathrm{r} \mathrm{Q}^{\text {ss }}{ }_{\mathrm{t}}
$$

in with $Q^{s s}$ is the total deposited flux of seston.

A comparison of $Q^{\text {ss }}{ }_{\text {auto }}$ at different depths (the lowest was the standard depth) is shown in Figure 3. The value of $a_{h}$ indicates the ratio of the trap depth to the water depth. The sums of $Q^{\text {ss }}{ }_{\text {auto }}$ for 106 days (11 sampling periods, Sta. 4) are 251, 294, and $335 \mathrm{~g} \cdot \mathrm{m}^{-2}$ for upper, middle, and lower traps, respectively. The depth of the production layer $(1-3 \mathrm{~m})$, the mineralization in the settling process, and the turbulence in lake water may affect the difference of deposition rates at different depths, and an estimate of those rates can be given by the rate observed at the standard depth $(0.5-1 \mathrm{~m}$ off the bottom).

Next, we examined the calculation of resuspension

Table 2. POC, PON, PP, and Chla concentrations of autochthonous matter (\%).

\begin{tabular}{lcccccc}
\hline & T 1 & T 2 & T 3 & T 4 & Aoko $^{1)}$ & Oceanic phytoplankton ${ }^{2)}$ \\
\hline POC & 37.1 & 39.1 & 36.8 & 32.8 & 37.7 & 35.9 \\
PON & 5.89 & 6.04 & 5.82 & 5.79 & 9.42 & 6.30 \\
PP & 0.60 & 0.62 & 0.65 & 0.60 & 0.70 & 0.87 \\
Chla & 0.55 & 0.85 & 0.92 & 0.67 & 0.56 & -
\end{tabular}

T1: July 1981 - October 1981, T2: June 1982 - September 1982, T3: November 1981 - May 1982, T4: April 1985 - May 1986, 1) Takamura et al. (1981), 2) $\left(\mathrm{CH}_{2} \mathrm{O}\right)_{106}\left(\mathrm{NH}_{4}\right)_{16} \mathrm{H}_{3} \mathrm{PO}_{4}$, Richards et al. (1965)

Table 3. POC, PON, PP, Chla, and Ti concentrations in lake and river water.

\begin{tabular}{llllll}
\hline & Sta. 2 & Sta. 4 & R. Koise & R. Amano & R. Sanno \\
\hline POC $\left(\mathrm{mg} \cdot 1^{-1}\right)$ & $6.11 \pm 7.12$ & $6.72 \pm 7.74$ & $1.15 \pm 0.72$ & $0.97 \pm 0.62$ & $3.75 \pm 3.21$ \\
PON $\left(\mathrm{mg} \cdot 1^{-1}\right)$ & $1.04 \pm 1.14$ & $1.12 \pm 1.21$ & $0.15 \pm 0.08$ & $0.14 \pm 0.07$ & $0.54 \pm 0.43$ \\
PP $\left(\mathrm{mg} \cdot 1^{-1}\right)$ & $.125 \pm .091$ & $.119 \pm .088$ & $.059 \pm .039$ & $.053 \pm .034$ & $.127 \pm .068$ \\
Chla $\left(\mu \mathrm{g} \cdot 1^{-1}\right)$ & $116 \pm 125$ & $128 \pm 134$ & $6.2 \pm 3.2$ & $8.3 \pm 8.9$ & $12.6 \pm 10.3$ \\
P-Ti $\left(\mathrm{mg} \cdot 1^{-1}\right)$ & $.083 \pm .083$ & $.053 \pm .038$ & $.095 \pm .077$ & $.069 \pm .072$ & $.133 \pm .318$ \\
\hline
\end{tabular}


rate $Q_{r \text { se }}^{\text {ss }}$ at the bottom of the lake. The first approximation of $\mathrm{Q}^{\text {ss }}$,e, which assumes a uniform concentration of resuspended matter in whole depths, and the settling of the matter in still water, lead to the following equation.

$$
Q_{\text {re }}^{\text {ss }}=\left(Q^{\text {ss }}{ }_{\mathrm{t}}-Q_{\text {auto }}^{\text {ss }}\right) / a_{h}
$$

Figure 4 shows a comparison of $Q_{\text {re }}^{\text {ss }}$ obtained by eq.(3) at different depths. The fairly good ageement indicates the appropriateness of this equation. Consequently, the autochthonous deposited rates of nutrients $\mathrm{Q}^{\mathrm{a}}{ }_{\text {auto }}$ ( $\mathrm{a}$ is the target substance) can be given by

$$
Q^{\mathrm{a}}{ }_{\text {auto }}=Q^{\mathrm{ss}} \mathrm{C}_{\mathrm{t}} \mathrm{a}_{\mathrm{d}}-\left(\mathrm{Q}^{\mathrm{ss}} \mathrm{t}_{\mathrm{t}}-\mathrm{Q}^{\mathrm{ss}}{ }_{\text {auto }}\right) \mathrm{C}^{\mathrm{a}}{ }_{\mathrm{s}}
$$

in which $\mathrm{C}_{\mathrm{d}}^{\mathrm{a}}, \mathrm{C}^{\mathrm{a}}{ }_{\mathrm{s}}$ are the concentrations of $\mathrm{a}$ in the

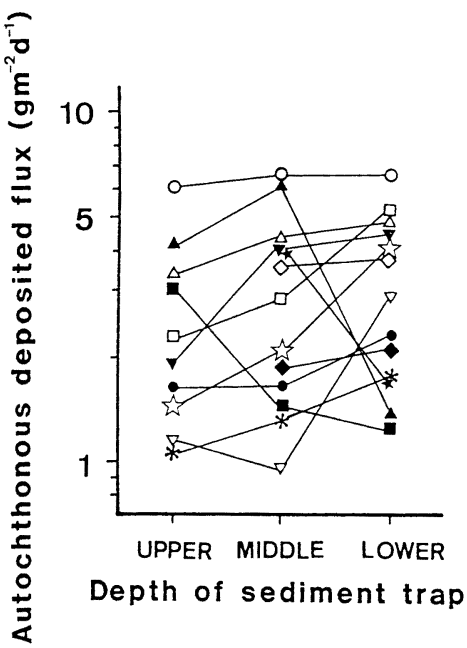

Fig. 3. Comparison of autochthonous deposited fluxes at different depths at Sta.4. Upper: $a_{h}=0.25$, Middle: $a_{h}=0.6$, Lower: $a_{h}=0.75$. deposited matter and sediments, respectively.

\section{3-2. Factors influencing autochthonous} deposition and resuspension rate

The seasonal, yearly, and stational variations in autochthonous deposited flux and resuspension rate are described here to elucidate the factors influencing these processes. Figure 5 shows the seasonal variations in autochthonous deposited flux of seston $\mathrm{Q}^{\text {ss }}{ }_{\text {auto }}$, resuspension rate $\mathrm{Q}^{\mathrm{ss}}$,e $\mathrm{SS}$ and Chla concentrations in lake water, amount of rainfall, and water

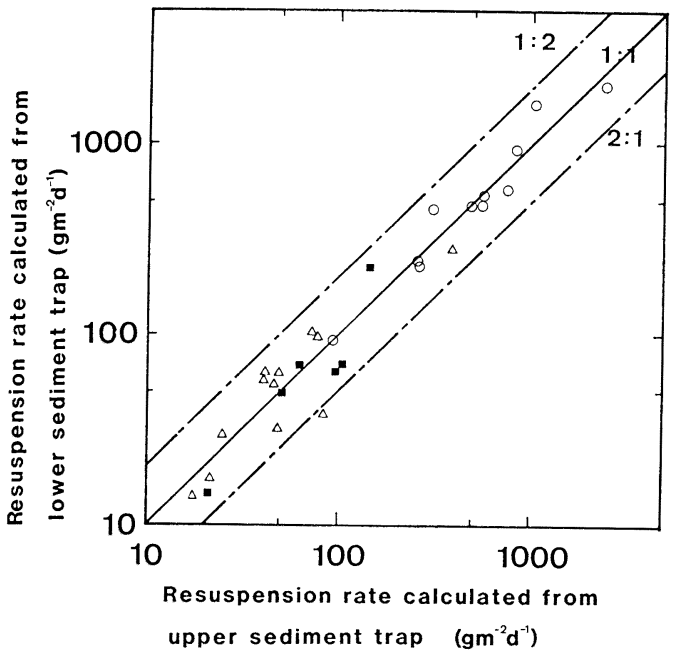

Fig. 4. Comparison of resuspension rates of sediments at bottom $Q^{\text {ss }}{ }_{\text {re }}$ obtained by eq. (3) at different depths. $\bigcirc$ : Sta.1 (Upper: $a_{h}=0.3$, Lower: $a_{h}=0.7$ ), $\triangle$ : Sta.4 (Upper: $a_{h}=0.6$, Lower: $a_{h}=0.75$ ), $\square$ : Sta.5 (Upper: $a_{h}=0.5$, Lower: $a_{h}=0.8$ ).

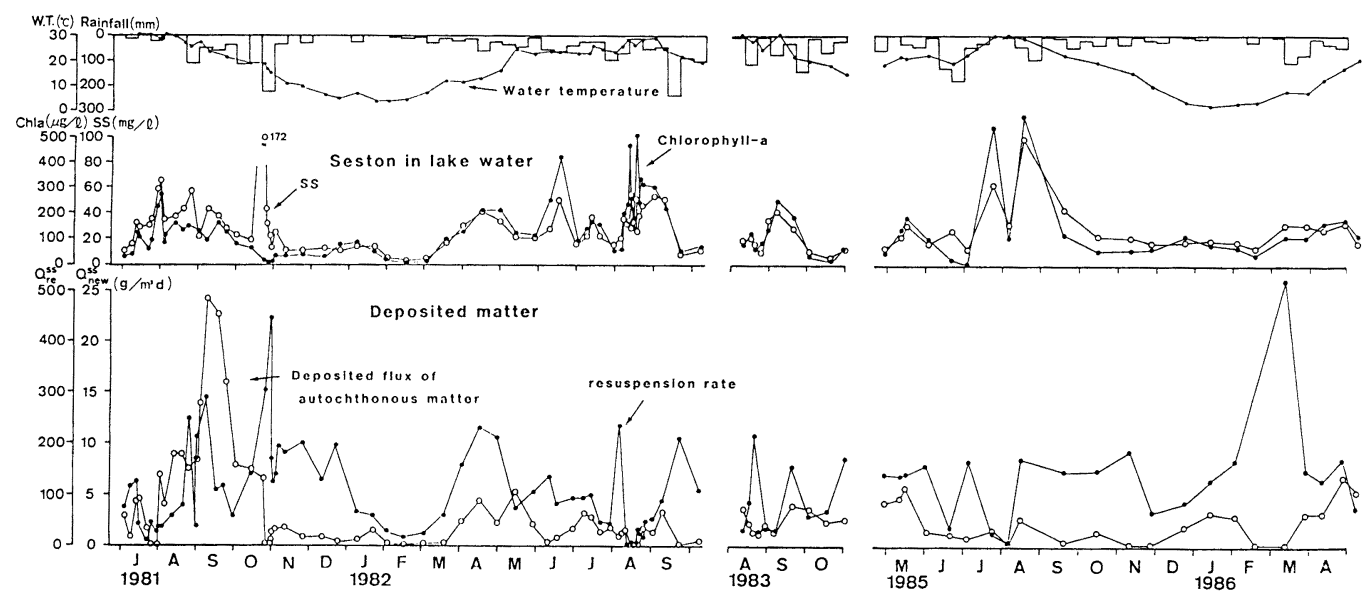

Fig. 5. Seasonal variations in autochthonous deposited fluxes of seston, resuspension rates, SS and Chla in lake water, amount of rainfall, and water temperature at Sta.3. 
temperature at Sta. 3. Nearly the same seasonal variations were also observed at other stations. Whereas Chla in lake water had two peaks in March-April and July-September, the peaks of $\mathrm{Q}_{\text {auto }}^{\text {ss }}$ were found in April-May and August September. No distinct seasonal variation was observed in $Q^{\text {ss }}{ }_{r e}$.

Annual deposited fluxes of seston, Chla, carbon, nitrogen, and phosphorus, as well as the means of SS and Chla in lake water and water depth at five stations for July 1981 -June 1982, are summarized in Table 4 . The fluxes of $\mathrm{Q}_{\text {auto }}^{\text {ss }}$ and $\mathrm{Q}_{\text {auto }}^{\text {chla }}$ are of nearly the same order of magnitude; the fluxes of $Q_{\text {auto, }}^{c}$, $\mathrm{Q}^{\mathrm{N}}{ }_{\text {auto, }}$ and $\mathrm{Q}^{\mathrm{P}}{ }_{\text {auto }}$ at Sta. 1 and 2 are much larger than those at Sta. 3, 4 and 5. The resuspension rate decreases with increasing mean water depth. Yearly comparisons of autochthonous fluxes of carbon and nitrogen at Sta. 3 for August-September are shown in Table 5. The mean Chla concentration in lake water, amount of rainfall, and air temperature are also tabulated. The values of $\mathrm{Q}^{\mathrm{C}}{ }_{\text {auto }}$ and $\mathrm{Q}^{\mathrm{N}}{ }_{\text {auto }}$ in 1981 were about twice those in other years. In this year, the mean Chla concentration was much lower.

With respect to the seasonal change in autochthonous deposited flux, Figure 6 shows the seasonal variations in primary production rate (Takamura et al., 1984) and autochthonous deposited flux of

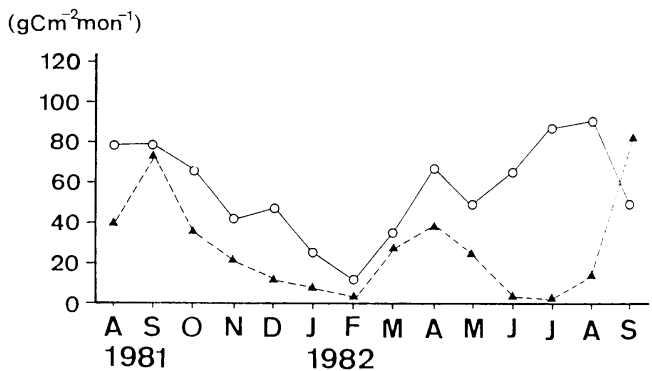

Fig. 6. Seasonal changes in primary production rate (O) and autochthonous deposited flux at Sta.5.

carbon at Sta. 5. Though the primary production rate had a clear peak in mid-summer, $Q^{c}{ }_{\text {auto }}$ had that in September. This time lag of one or two months explained the surprising increase in lake Chla concentration in mid-summer (Fig. 5). A similar seasonal variation in autochthonous flux had been observed in Lake Wignra with a mean depth of $2.4 \mathrm{~m}$ (Gasith, 1975). Deeper lakes possessing a stable thermocline in summer had considerably different patterns according to which the deposited flux of autochthonous matter had two peaks in spring and fall (Lastein, 1976; Fukushima et al., 1988).

Table 4. Annual deposited fluxes of seston, Chla, carbon, nitrogen, and phosphorus at five stations for July 1981 - June 1982.

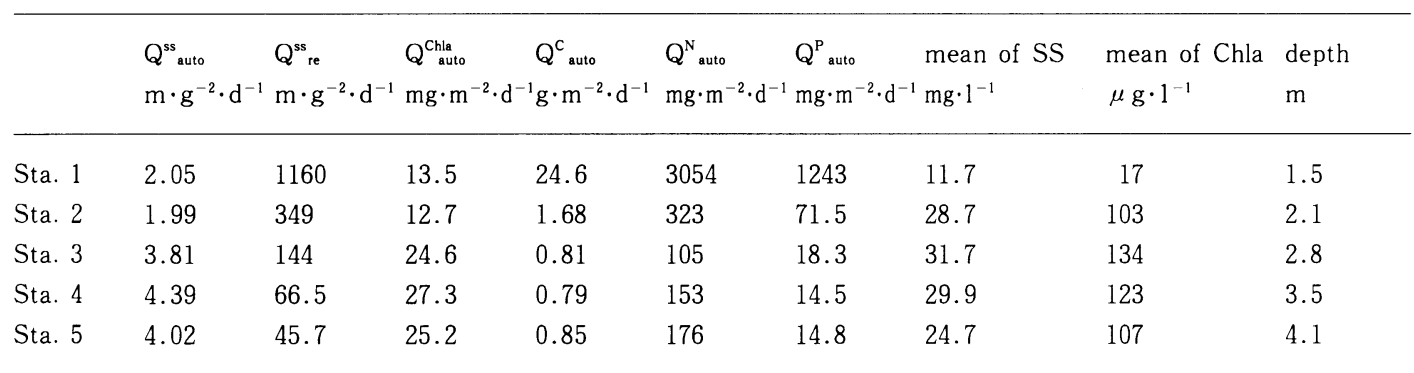

Table 5. Yearly comparison of autochthonous fluxes of carbon and nitrogen at Sta. 3 for August - September.

\begin{tabular}{lllll}
\hline & 1981 & 1982 & 1983 & 1985 \\
\hline $\mathrm{Q}^{\mathrm{C}}{ }_{\text {auto }}\left(\mathrm{mg}^{-2} \cdot \mathrm{m}^{-2} \cdot \mathrm{d}^{-1}\right)$ & 4040 & 1294 & 1293 & 2140 \\
$\mathrm{Q}^{\mathrm{N}}{ }_{\text {auto }}\left(\mathrm{mg}^{-2} \cdot \mathrm{m}^{-2} \cdot \mathrm{d}^{-1}\right)$ & 601 & 385 & 339 & 270 \\
mean of Chla $\left(\mu \mathrm{g} \cdot \mathrm{l}^{-1}\right)$ & 132 & 238 & 169 & 234 \\
Rainfall $(\mathrm{mm})$ & 251.5 & 511.0 & 370.0 & 201.5 \\
Air temperature $\left({ }^{\circ} \mathrm{C}\right)$ & 21.9 & 22.6 & 22.9 & 23.7
\end{tabular}


It could be inferred that the depth of the lake and the condition of water movement affect the seasonal change in autochthonous deposited flux. In addition, the rates of autochthonous deposited flux divided by Chla concentration in lake water were higher in spring peaks than in summer peaks except in the summer of 1981 (Fig. 1): The difference in the dominant species of phytoplankton (spring: diatoms such as Synedra and Cyclotella ; summer: blue-green algae as Microcystis and Anabaena, Takamura et al., (1984)) would change the degree of the contribution of deposition and that of mineralization to the decline of autochthonous matter.

For the stational variations in autochthonous fluxes, two factors should be considerd: primary production rate and influence of allochthonous matter. The primary production rates measured at Sta. 3, 4 and 5 for October 1981-September 1982 amounted to 698,606 , and $643 \mathrm{gC} \cdot \mathrm{m}^{-2} \cdot \mathrm{yr}^{-1}$, respectively (Takamura et al., 1984). Insignificant stational differences in $Q^{\text {ss }}$ auto and $Q_{\text {auto }}^{\text {chla }}$ would result from these nearly same conditions in primary production. On the other hand, the higher values of $Q^{c}{ }_{\text {auto, }}$, $\mathrm{Q}^{\mathrm{N}}{ }_{\text {auto, }}$ and $\mathrm{Q}^{\mathrm{P}}{ }_{\text {auto }}$ at Sta. 1 and 2 than Sta. 3, 4 and 5 could be attributed to the contamination of autochthonous deposited matter by allochthonous deposited matter. Since carbon, nitrogen, and phosphorus contents in allochthonous matter are higher than those in sediments (Table 1, 3), the sample contaminated by allochthonous matter shows apparently higher of autochthonous carbon, nitrogen, and phosphorus deposited fluxes than their original values (if the ratio $r$ is calculated by eq. (1)). In the backwater region or near the mouth of the inflow river, it should be noted that the allochthonous deposited fluxes cannot be neglected.
There were considerable stational differences in resuspension rates, which were attributable to the difference in stress exerted on sediments. In a shallow lake, wind driven current, wind wave, and river induced current are thought to be major sources of stress. Table 6 shows the correlation coefficients between $\mathrm{Q}^{\text {ss }}{ }_{\text {re }}$ and some meteorological value averaged for each sampling period. The rainfall roughly represents the river induced current; the square and the cube of daily maximum wind velocity imply the stress and the energy exerted by wind on a water surface, respectively. As shown in Table 6, significant correlations with $\mathrm{Q}_{\text {re }}^{\text {ss }}$ are found in the amount of rainfall at Sta. 1 and in the cube of wind velocity at all stations except for Sta. 2 . The logarithmic decrease in $\mathrm{Q}_{\text {re }}^{\text {ss }}$ against water depth (Table 4) possibly originates from the effect of wave action (Otsubo and Muraoka, 1985), but quantitative discussion cannot be conducted because of no information on the frequency distribution of wave height, the relation between the stress and the resuspension rate, etc. In a shallow lake, the resuspension of sediments must be taken into account anyhow, considering the larger proportion in deposited flux even in the offshore region.

As shown in Table 5 , the yearly differences in $\mathrm{Q}^{\mathrm{C}}{ }_{\text {auto }}$ and $\mathrm{Q}^{\mathrm{N}}{ }_{\text {suto }}$ are not small. There were no great differences in the net photosynthesis rates of those years (Takamura, 1987). The influence of allochthonous matter would be rejected, because lower values of $Q^{C}{ }_{\text {auto }}$ and $Q^{N}{ }_{\text {auto }}$ were observed in the years having a larger amount of rainfall. In regard to the differences between 1981 and 1982, the difference in the compositions of the main species of phytoplankton is thought to be one of the causes. Microcystis aeruginosa was the dominant species in both summer, but the biomass of

Table 6. Correlation coefficients between resuspension rate of sediments and some meteorological conditions.

\begin{tabular}{lllll}
\hline & $\begin{array}{l}\text { Amount of } \\
\text { rainfall }\end{array}$ & $\begin{array}{l}\text { Average of } \\
\text { daily maximum } \\
\text { wind velocity }\end{array}$ & $\begin{array}{l}\text { Square of } \\
\text { daily maximum } \\
\text { wind velocity }\end{array}$ & $\begin{array}{l}\text { Cube of } \\
\text { daily maximum } \\
\text { wind velocity }\end{array}$ \\
\hline Sta. 1 & $0.503 \star$ & 0.256 & 0.341 & $0.341 \star$ \\
Sta. 2 & 0.012 & 0.139 & 0.156 & 0.196 \\
Sta. 3 & 0.069 & 0.298 & $0.387 \star$ & $0.433 \star$ \\
Sta. 4 & $0.412 \star$ & 0.270 & $0.414 \star$ & $0.527 \star$ \\
Sta. 5 & $0.394 \star$ & 0.097 & 0.222 & $0.337 \star$ \\
\hline
\end{tabular}

^ means the value of correlation coefficient $\left(r_{c}\right)$ which rejects the null phypothesis $r_{c}=0$ at the level of significance 0.01 . 
Anabaena flos-aquae and Aphanizomenon flosaquae was not negligible in the summer of 1982 (Takamura et al., 1984). Fallon and Block (1980) pointed out that decomposition appeared to be primarily important for Anabaena and Aphanizomenon, whereas sedimentation accounted for more of the decline of Microcystis. In 1981, experiments to measure the decomposition rate of seston were conducted under the conditions of $20{ }^{\circ} \mathrm{C}$, in a darkened condition, and by stirring with a magnetic stirrer. The decomposition rates of Chla in the rapid step during the first two weeks were calculated as a first-order reaction coefficient and found to be $0.096 \pm 0.057 \mathrm{~d}^{-1}(\mathrm{n}=7)$ for June-July, $0.0047 \pm 0.0062$ $\mathrm{d}^{-1}(\mathrm{n}=4)$ for August-September, and $0.098 \pm 0.040$ $\mathrm{d}^{-1}(\mathrm{n}=7)$ for October-December. The lower rates for August-September correspond to the higher autochthonous deposited fluxes for this period. It can therefore be presumed that varieties of phytoplankton species affect the autochthonous deposited fluxes. In addition, it was noted that the mean Chla

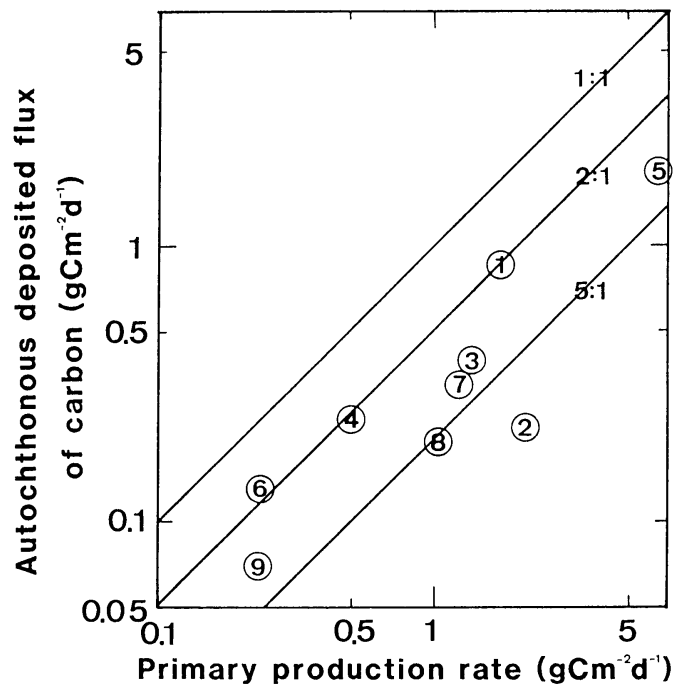

Fig. 7. Relationship between primary production rate and autochthonous deposited flux in the nine lakes. 1: This study, 2: Lake Suwa (mean depth 4.1m, Hayashi (1973)), 3: Lake Rotsee (9.0m, Bloesch et al. (1976)), 4: Lake Esrom (12.3m, Lastein (1976)), 5: Lake Mendota (12.4m, Fallon and Brock (1980)), 6: Lake Kizaki $(17.9 \mathrm{~m}$, Koyama et al. (1975)), 7: Lake Lugano (33m, Premazzi and Marengo (1982)), 8: Lake Lucerne (43m, Bloesch et al. (1977)), 9: Lake Chuzenji (94m, Fukushima et al. (1988)). concentration of lake water was lower in 1981 when $\mathrm{Q}^{\mathrm{C}}$ auto and $\mathrm{Q}^{\mathrm{N}}{ }_{\text {auto }}$ were larger. We cannot conclude now which is the cause or which is the result, but it should be noted that the autochthonous deposited fluxes are related to the Chla concentration of the lake water.

Finally, we compared the ratio of the autochthonous deposited flux to the primary production rate with those observed in other lakes. In the Takahamairi Bay, these ratios were calculated to be 0.32 , 0.54 , and 0.44 for Sta. 3, 4 and 5, respectively. For the lakes where the resuspension of sediments is negligible and/or the lakes where the separation method was applied, Figure 7 shows the relationship between the primary production rate and the autochthonous deposited flux of carbon. Except for Lake Suwa, the ratio ranges from $1 / 6$ to $1 / 2$. In Lake Suwa, sediment traps of funnel, which were known to underestimate the deposited flux in stormy conditions (Bloesch and Burns, 1978), were deployed (Hayashi, 1973). The values ranging from $1 / 6$ to $1 / 2$ are therefore considered as appropriate for the ratio.

\section{3-3. Comparison of autochthonous deposited fluxes with net sedimentation rates}

There are two methods estimate the net sedimentation rates: (1) the mass balance method (Golterman, 1975) and (2) the sediment dating method (Krishnaswani and Lai, 1978). The mass balance method for total nitrogen and total phosphorus was applied to Box-1 (Fig. 1) every month for January 1978 -December 1980 (Goda et al., 1984). Inflow from river, rain, culture of carp and outflow by advection, dispersion, fishing, some water supplies and emergence of Chironomid were taken into account in the mass balance. The denitrification rate in sediments (Aizaki et al., 1981) was evaluated for total nitrogen. As described in the previous section, the sediment accumlation rate was estimated to be $600-800 \mathrm{~g} \cdot \mathrm{m}^{-2} \cdot \mathrm{yr}^{-1}$ as dry weight. Multiplying this ratio by the composition of sediments, we obtained the carbon, nitrogen, and phosphorus accumulation rates into sediments. Table 7 shows the autochthonous deposited fluxes (Sta. 5 , July 1981 -June 1982), the allochthonous deposited fluxes, residuals in mass balance (averaged for January 1978 -December 1980), and sediment accumulation rates (sediments compositions at Sta. 5). The allochthonous deposited fluxes were estimated by the presumption that all of the particulate components in inflow matter settle in this box. The 
Table 7. Autochthonous deposited fluxes (Sta. 5, July 1981-June 1982), allochthonous deposited fluxes, residuals in mass balance (January 1978-December 1980), and sediment accumulation rates $\left(\mathrm{g} \cdot \mathrm{m}^{-2} \cdot \mathrm{yr}^{-1}\right)$.

\begin{tabular}{lllll}
\hline & $\begin{array}{l}\text { Autochthonous } \\
\text { deposited fluxes }\end{array}$ & $\begin{array}{l}\text { Allochthonous } \\
\text { deposited fluxes }\end{array}$ & $\begin{array}{l}\text { Residuals in mass } \\
\text { balance including } \\
\text { denitrification } \\
\text { in sediments }\end{array}$ & $\begin{array}{l}\text { Accumulation } \\
\text { rates in sediments }\end{array}$ \\
\hline Carbon & 310 & & & $38.7-51.6^{2)}$ \\
Nitrogan & 64.2 & 11.8 & $7.2-9.8^{1)}$ & $4.4-5.8^{2)}$ \\
Phosphorus & 5.4 & 3.8 & 3.8 & $1.0-1.4^{2)}$ \\
\hline
\end{tabular}

1) Residual in mass barance $=17.1 \mathrm{~g} \cdot \mathrm{m}^{-2} \cdot \mathrm{yr}^{-1}$, denitrification in sediments $=7.3-9.9 \mathrm{~g} \cdot \mathrm{m}^{-2} \cdot \mathrm{yr}^{-1}$, 2) sediment accumulation rate in dry weight $=600-800 \mathrm{~g} \cdot \mathrm{m}^{-2} \cdot \mathrm{yr}^{-1}$

proportions of the particulate component in total inflow load were $31 \%$ for nitrogen and $66 \%$ for phosphorus (Matsuoka, 1984).

The sums of autochthonous and allochthonous deposited fluxes exceed the residuals in mass balance and accumulation rates in sediments by a factor of $8-17$ for nitrogen and by a factor of $2-10$ phosphorus. The mass balance method has some errors due to inaccuracies in determining the inflow loads during direct runoff period etc., and the sediment dating method does not take into consideration the horizontal variations in sediment accumulation rates and sediment compositions. In addition, the allochthonous deposited fluxes were slightly overestimated owing this presumption. The differences between them are, however, so great that we cannot assume only one - way transport from water to sediments. Nutrient release rates from sediments under aerobic conditions, which is one of the counter transport processes, were $11.3 \mathrm{~g} \cdot \mathrm{m}^{-2}$. $\mathrm{yr}^{-1}$ for nitrogen and $0.92 \mathrm{~g} \cdot \mathrm{m}^{-2} \cdot \mathrm{yr}^{-1}$ for phosphorus (Hosomi and Sudo, 1984). It is well known that the release of nutrients increases dramatically under anaerobic conditions, and the turnover through the activity of benthos has high rates in some seasons (Goda et al., 1984). In a shallow lake, it could be inferred that the return flow from sediments to water is nearly as great as the freshly deposited flow. In addition, the reason for the higher return rate of nitrogen than phosphorus is the higher decomposition rate in particulate organic matter, the lower proportion of particulate components in allochthonous matter, and the higher proportion of dissolved components in fish excretion (Goda et al., 1984).

In Lake Mendota, of the original organic matter, $89 \%$ (57\% then occurred in the water column and another $32 \%$ at the mud surface) was decomposed before the material was buried in the sediments (Fallon and Brock, 1980). The ratio of the decomposed matter in sediments to the matter reaching the sediments was $76 \%$. These ratios were reported to be $46 \%, 47 \%$ and $25 \%$ for carbon, nitrogen, and phosphorus in Lake Lugano (Premazzi, 1982) and $33 \%$ and $65 \%$ for carbon and nitrogen, respectively, in Lake Kizaki (Koyama et al., 1975). These ratios are slightly lower than those in the Takahamairi Bay (over $80 \%$ for nitrogen and phosphorus).

Using the natural phytoplankton communities of Lake Kasumigaura, Aizaki and Takamura (1986) pointed out the decomposition rates of particulate nitrogen under static conditions were about 0.7 times as great as those under aerating conditions. Further, the annual mean biomass and annual production of $T$. akamusi in Takahamairi Bay $(1977-1983)$ were $5.7 \mathrm{~g} \cdot \mathrm{C} \cdot \mathrm{m}^{-2}$ and $8.8 \mathrm{gC} \cdot \mathrm{m}^{-2} \cdot \mathrm{yr}^{-1}$, respectively, and those for $C$. plumosus were $1.2 \mathrm{gC} \cdot \mathrm{m}^{-2}$ and $6.5 \mathrm{gC} \cdot \mathrm{m}^{-2} \cdot \mathrm{yr}^{-1}$, respectively (Iwakuma et al., 1984). In winter, the standing crop of Neomysis intermedia was $56.76 \mathrm{~g} \cdot \mathrm{m}^{-2}$ in wet weight (Kasuga, 1981). These high densities of benthic animals would correspond to the high eutrophication level of this lake and could provide the major pathway of nutrients from sediments to water. The shallowness of this lake results in a lowering of the proportion of buried material in sediments because of the large resuspension rate followed by rapid decomposition in lake water and high activity of benthos.

\section{摘 要}

\section{霞ケ浦高浜入りにおける自生性沈殿と 底泥の巻き上げ現象の特徵}

霞ケ浦高浜入りの 5 地点に拈いて，1981－1986年の ある期間, セジメントトラップを用いて沈殿物を採集 し, 分析した。 
1）クロロフィルaを指標物質として沈殿物の起源 を自生性懸濁物と巻き上げられた底泥に分離する方式 を検討した。湖水中懸濁物組成の時間的変化, 水深の 異なる位置での沈殿量の違い, チタン等をトレーサー にした場合の分離結果等から考光てこの方式が適切か つ有効であることを示した。

2）高浜入中央部に拈いても，年平均值として自生 性沈殿量 $4 \mathrm{gm}^{-2} \cdot \mathrm{d}^{-1}$ に対して底泥巻き上げ量は 46 $\mathrm{gm}^{-2} \cdot \mathrm{d}^{-1}$ ときわめて大きいことが明らかになった。自 生性の沈殿量は植物プランクトンの一次生産量の変化 に約 1,2 力月の時間遅れを有しつつ追随して変化す ること, 流入河川の背水域, 河口近傍では有機態の炭 素, 窒素, 抒よびリンの沈殿量が多く外来性懸濁物の 沈殿が影響していると考元られること，底泥の巻き上 げ量はその対数が水深にほぼ逆比例するとともに風 速，降水量と有意な関係を有することがわかった。

3）高浜入を 1 ボックスとした物質収支算定から得 られる収支残量，および年代測定結果を考慮した底泥 への蓄積速度と比例して, 自生性, 外来性沈殿量の和 は, 窒素で $8-17$ 倍, リンで $2-10$ 倍も多く, 再巻き 上げ時の湖水中での分解速度の早さ, 底生動物の盛ん な活動を通して, 底泥から湖水への栄着塩の回帰量が きわめて大きいことを示唆した。

\section{References}

AIZAKI, M. et al. (1981) : Budget of nutrients at Takahamairi Bay, Lake Kasumigaura. Res. Rep. Natl. Inst. Environ. Stud. Jpn., No.22: 281-307 (in Japanese).

AIZAKI, M. and N. TAKAMURA (1986) : Nutrient regeneration by decomposition of lake phytoplankton. Res. Rep. Natl. Environ. Stud. Jpn., No.96: 29-44 (in Japanese).

BloEsCH, J. et al. (1977) : Primary production, mineralization, and sedimentation in the euphotic zone of Swiss lake. Limnol. Oceanogr., 22: $511-526$.

BloEsCH, J., and N. M. BURNS (1980) : A critical review of sedimentation trap technique. Schweiz.Z. Hydrol., 42: 15-55.

FALLON, R. D., and T. D. BRock (1980) : Planktonic blue-green algae: production, sedimentation, and decomposition in Lake Mendota, Wisconsin. Limnol. Oceanogr., 25: 72-88.

FuHs, G. W. (1973) : Improved device for the collection of sedimenting matter. Limnol. Oceanogr., 18: 989-993.

FukUSHIMA, T. et al. (1984) : Method to collect deposited matter and the separation of autochthonous matter and resuspended sediments in a shallow lake. Res. Rep. Natl. Inst. Environ.
Stud. Jpn., No.51: $73-87$ (in Japanese).

FunUSHima, T. et al. (1987) : Characteristics of particulate matter compositions and its relation to sediment conpositions near the mouth of influenet river. Proc. Environ. Sani. Eng. Res., 23: $31-40$ (in Japanese).

FUKUSHIMA, T. et al. (1988) : Characteristics of deposited matter and its role in nutrient cycles in a deep lake. (to be published in Hydrobiologia).

GARDNER, W. D. (1980) : Sediment trap dynamics and calibration: a laboratory evaluation. J. Mar. Res., 38: 17-39.

Gasith, A. (1975) : Tripton sedimentation in eutrophic lake. Vehr. Internat. Verein. Limnol., 19: $116-122$.

Golterman, H. L. (1975) : Physiological limnology. An approach to the physiology of lake ecosystems, p.357-402. In Deveolpments in water science, V.2. Elsevier.

GodA, T. et al. (1984) : Phosphorus and nitrogen budget in Lake Kasumigaura. Res. Rep. Natl. Environ. Stud. Jpn., No.54:31-40 (in Japanese).

HAYASHI, H. (1973) : Deposition rate of organic matter in 1971 and 1972. Prog. Rep. Lake Suwa, 5: 40-43 (in Japanese).

Hosomi, M. and R. Sudo (1984) : Release of nitrogen and phosphorus from sediments of Lake Kasumigaura. Res. Rep. Natl. Inst. Environ. Stud. Jpn., No.51: 191-217 (in Japanese).

IwAKUMA, T. et al. (1984) : The distribution and production of zoobenthos, and the role of Chironomids in the matter flow in Lake Kasumigaura.Res. Rep. Natl. Inst. Environ. Stud. Jpn., No.51:103-140 (in Japanese).

KASUGA (1981) : Estimation of the seasonal changes in standing crops of fishes, freshwater shrimp and opossum shrimp at Takahamairi Bay in Lake Kasumigaura. Res. Rep. Natl. Inst. Environ. Stud. Jpn., No.22: 159-169 (in Japanese).

Koy AmA, T. et al. (1975) : Geochemical studies on the cycle of carbon and nitrogen in a mesotrophic lake. JIBP Synthesis, 12: 115-123.

KRISHNASWANI, S. and D. LAI (1978) : Radionuclide limnochronology, p.153-177. In A. Lerman (ed.), Lakes: Chemistry, Geology, Physics. Springer-Verlag.

LASTEIN, E. (1976) : Recent sedimentation and resuspension of organic matter in eutrophic Lake Esrom, Denmark. OIKOS, 29: 44-49.

MATSUNAGA, K. (1982) : An estimation of allochtho- 
nous and autochthonous organic matter of the fresh sediments on the basis of $\mathrm{Ti}$ content. Jpn. J. Limnol., 43: 113-120.

MATSUOKA, Y. (1984): An eutrophication model of Lake Kasumigaura Res. Rep. Natl. Inst. Environ. Stud. Jpn., No.54:53-242 (in. Japanese).

OKamoto, K. and K. Fuwa (1984) : Low-contamination digestion bomb method using a teflon double vessel for biological materials. Anal. Chem., 56: 1758-1760.

Otsubo, K. and K. MuraoKa (1985) : Field observation and simulation of cohensive sediments resuspension in Lake Kasumigaura. Proc. 29th Japan Conference on Hydraulics: $353-358$ (in Japanese).

OTSUBO, K. et al. (1984) : Characteristics of physical properties and nutrients distributions of mud in Lake Kasumigaura. (1) Distribution of physical properties. Res. Rep. Natl. Environ. Stud. Jpn., No.51: $157-173$ (in Japanese).

Premazzi, G. and G. Marengo (1980) : Sedimentation rates in a Swiss-Italian lake measured with sediment traps. Hydrobiologia, 92: 603-610.

RichaRDS, F. A. et al. (1965) : Some consequences of the decomposition of organic matter in Lake Nitinat. Limnol. Oceanogr., 10 (Supplement): R185-R201

UNESCO (1966) : Determination of photosynthetic pigments in sea water. Monographs on oceanographic methodology 1, UNESCO Pub. Center.
TAKamatsu, T. (1978) : Multi-element analyses of rock and sediment samples by non-dispersive $\mathrm{X}$ - ray fluorescence. Bunseki kagaku, 27: 193-198 (in Japanese).

TAKAMURA, N. et al. (1984) : The biomass and production of phytoplankton in Lake Kasumigaura during 1981-1983. Res. Rep. Natl. Inst. Environ. Stud. Jpn., No.51:11-56 (in Japanese).

TAKAMURA, N. (1987) : Ecological studies on Microcystis in hypertrophic Lake Kasumigaura. Ph.D. Thesis to the Nara Women's University, p.1-182.

TAKAMURA, Y. et al. (1981) : Chemical compositions of Aoko (Microcystis) in Lake Kasumigaura and Microcystis aeruginosa in the pure culture. Res. Rep. Natl. Inst. Environ. Stud. Jpn.,No.25: 31-46 (in Japanese).

WATANABE, Y. and H. HAYASHI (1971) : Investigation on the method for measuring the amount of freshly precipitating matter in lakes. Jpn. J. Limnol., 32: 40-45 (in Japanese).

（著者：福島武彦, 相崎守弘, 村岡浩爾, 国立公害研 究所水質土㙥環境部, 干305 茨城県つくば市小野川1 6-2 ; Takehiko FukUSHIMA, Morihiro AIZAKI, Kohji MurAOKA, Water and Soil Environment Division, the National Institute for Environmental Studies, Onogawa 16-2 Tsukuba, Ibaraki 305.)

Received : 1 June 1987

Accepted : 23 October 1987 